\title{
Russia's Agro Industrial Complex: Economic and Political Influence Factors and State Support
}

\author{
V. P. Samarina ${ }^{1(\bowtie)}$, T. P. Skufina ${ }^{2}$, A. V. Samarin ${ }^{1}$, \\ and S. V. Baranov ${ }^{3}$ \\ 1 "MISIS" National Research Technological Federal University, \\ Staryy Oskol Technological Institute Branch, Staryy Oskol, Russian Federation \\ samarinavp@rambler.ru \\ ${ }^{2}$ Russian Academy of Sciences, Luzin Institute for Economic Studies \\ of the Kola Science Centre, Apatity, Russian Federation \\ 3 Belgorod State National Research University, Staryy Oskol Branch, \\ Staryy Oskol, Russian Federation
}

\begin{abstract}
Authors consider changes in Russian agro-industrial complex un regard to international marketing, management and business strategies. The aim of the study is to identify the specifics of the differentiation trends in the socioeconomic space of the Russia. Basing on the Russia's Federal Agency of State Statistics official materials (from 1991 to 2016), authors of the proposed research have estimated Russia's agricultural ability to react to external changes. They reveal natural and climatic factors which have direct and essential influence on agricultural development. Authors give practical recommendations for the formation of an agriculture state domestic support mechanism.
\end{abstract}

Keywords: Russian economy $\cdot$ Sanctions $\cdot$ Counter sanctions $\cdot$ Food safety $\cdot$ Economic and political factors - Agricultural production - State support

\section{Introduction}

The agriculture is the major sector of Russian economy. Domestic agricultural production underlies security of food safety of the country. The problem of working out measures of domestic state support of Russian agro industrial complex on the basis of analysis of external economic-political and other factors of its development is rather actual. A lot of under-mentioned aspects determine this urgency.

First, Russian economy in many ways continues to depend on external conditions, including political ones. Secondly, public management in Russia is absolutely centralized and as a result state resolutions often have influence on sectors of economy development. Thirdly, external and internal political factors have led to change of institutional conditions of production of agricultural products. Fourthly, agriculture development in Russia is restrained by some unfavourable natural and climatic conditions and absence of modern material and technical base. Fifthly, measures of domestic state support of Russian agriculture are limited with World Trade 
Organization regulations. Sixthly, there is a necessity of Russian economy diversification which has pronounced raw character. One of diversification directions is agricultural production development. Thus, on the one hand, agro industrial complex development answers modern and perspective purposes of Russia's economy development. On the other hand, political resolutions have strong influence on agro industrial complex development.

The research problem consists in the following: external economic and political factors over a period of several years directly influence Russian agro industrial complex. And it affects social and economic development of Russia on the whole. Thus, the mechanism of domestic state support of Russian agro industrial complex is not finally developed.

The purpose of the article is the development of theoretical and methodological methods of studying economic and political factors influence the development of Russian agro industrial complex and the development of action-oriented recommendation directed at the formation of the mechanism of domestic state support of Russian agro industrial complex.

For the achievement of this purpose it is necessary to resolve a complex of interconnected problems:

- To reveal the dynamics of agro industrial complex development over a period of several years;

- To determine the agro industrial complex place in Russia's economy;

- To analyze the economic, political and other factors influence on the development of Russian agriculture;

- To develop action-oriented recommendations for the state domestic support of agricultural manufacturers under present-day conditions.

In the research we have come from some hypotheses:

A. Agriculture is one of the most dynamically developing sectors in Russia's economy;

B. Russia's agro industrial complex dynamically reacts to external changes;

C. Besides natural and climatic factors some special economic and political ones have material influence on agriculture development;

D. Countersanctions undoubtedly exert positive influence upon Russia's agricultural production development.

\section{Literature Review}

Economic and political factors to some extent had always influence on agriculture development worldwide. And governments of majority of countries tried to develop measures of domestic agrarian policy taking into account this influence. On the ground of historical documents studying, Johan F.M. Swinnen, for example, notes serious changes which took place in agricultural policy in Europe after 1860. During this period European countries had reconciled a number of trading agreements which then extended free trade on the continent. The author even calls these changes Dramatic 
changes on the assumption of force of their influence on European countries' agro industrial complex in XIX-th century (Swinnen 2009).

In the XX-th century World War I and World War II had huge influence on agriculture development. In a period of time between the wars state support was caused with the necessity of economic recessions overcoming in 1920s and 1930s. Eva Fernandez wrote about it in detail (2016). The General Agreement on Tariffs and Trade (GATT) is worth mentioning. Its activity began in 1947. So is the World Trade Organization (WTO) which succeeded GATT in 1994. The effects of these documents approval for agriculture were considered in the works of such authors as Baldwin (1985), Olson (1965), Barberis (2013).

Activity within GATT/WTO framework for agriculture of the countries which have joined the agreement assumed their successful development in new institutional conditions but as it turned out a number of problems took place. Stigler (1971), Swinnen et al. (2016) and other researchers investigated a question of comparison of empirical data with theoretical models of agriculture development. The governments of the USA and some European countries sometimes broke GATT/WTO rules for the purpose of their countries protection against agricultural products import and increase of food safety. Anderson (2009), Bagwell and Staiger (2006), Josling (2000), de Gorter and Swinnen (2002), Guariso et al. (2014) in their works quantitatively estimated agriculture development, connected it with political changes and offered some measures for agriculture protection of rich and poor countries.

Russia has lived under market economy laws for only 26 years, joining the WTO only 5 years ago. These are extremely short terms. Russia's agriculture, as well as other sectors of economy, changes by leaps and bounds. The state support policy of national manufacturers is in the stage of formation. We wrote about it in our published works (Samarina et al. 2016). But many problems of economic and political factors influence on agriculture development are still unsolved.

\section{Methodology}

In order to corroborate or refute the hypothesis that agriculture plays an important part in Russia's economy Russia's Federal State Statistics Service data have been used (Gross Domestic Product 2017).

They were taken as a principle of calculations. The attraction of official sources of the information raises the degree of credibility of results. The long space of time allows to estimate the dynamics of indicators change and reveal objective laws.

The dynamics of agro industrial complex development was estimated by means of volume indexes of agriculture production. For comparability of results indexes have been calculated in percentage terms to the level of 1991. Calculations results for obviousness have been presented on the diagram.

Values of manufacturing work indicator on some principal kinds of economic activities have been examined. The gross added cost of Russia's domestic product is a margin between cost of goods and services produced in certain year and intermediate consumption for the purpose of other goods and services producing. Total values of gross added cost by economic activities kinds take part in calculation of Russia's gross 
domestic product by means industrial method (Skufina et al. 2015). Values of gross added cost indicators of gross domestic product in established prices have been used in the article.

The change of indicators values of produced gross domestic product is connected firstly, with an inflation, and secondly, with a production activity intensity. The inflation leads to proportional growth of all indicators. Besides inflation exerts essential influence on indicators growth. It can prevent revealing of factors not connected with inflationary processes. For elimination of this lack values of gross added cost by kinds of economic activities and Russia's gross domestic product were converted in comparable prices. 2011 was taken as a principle. The procedure of recalculation of effective values of gross domestic product and its production components to the comparable prices was put into practice by means of extrapolation methods. They consist in multiplication of goods and services cost in appropriate previous period by the index reflecting change of goods and services volume. The data of Russia's Federal State Statistics Service from 2011 till 2016 have been used.

On the basis of Russia's Federal State Statistics Service data the author by means of a chain method calculates indexes of the volume of gross added cost on some principal kinds of economic activities: agriculture (AC), mining operations (MO) and processing manufacture (PM). By means of vertical and horizontal analyses indicators were compared with each other and with the index of Russia's gross domestic product volume. Indexes have been calculated and analyzed in established and comparable prices.

Russia's gross domestic product (GDP) structure was examined in sections of AllRussian Qualifier of Economic Activities Kinds (AQEAK). In Russia this qualifier was introduced into practice in February 2014. It is a part of structure of official All-Russian qualifiers of the technical and economic and social information. The European analogue of AQEAK is Statistical Classification of Economic Activities in the European Economic Community.

On the basis of the annual data about Russia's produced GDP values on AQEAK sections the author has calculated shares of separate kinds of economic activities in GDP structure. According to AQEAK structure the agriculture is merged in one section with hunting, fishery and fish culture. In our research we have not divided these kinds of activity and for the convenience designated them as "agriculture". We have compared the agriculture share in GDP structure with a share of mining operations and processing manufacture. According to the results of calculations the diagram which shows the dynamics of change of Russia's GDP structure according to principal activity category has been drawn.

For revealing of synchronism or asynchrony of index numbers changes the author has drawn up correlation matrix between gross added cost index numbers of agriculture, mining operations, processing manufacture and appropriate shares in Russia's GDP structure. This matrix has allowed to reveal proportional dependence between index numbers. 


\section{Results and Discussion}

On the Fig. 1 we represent volume indexes of agro industrial complex production in percentage terms to the level of 1991.

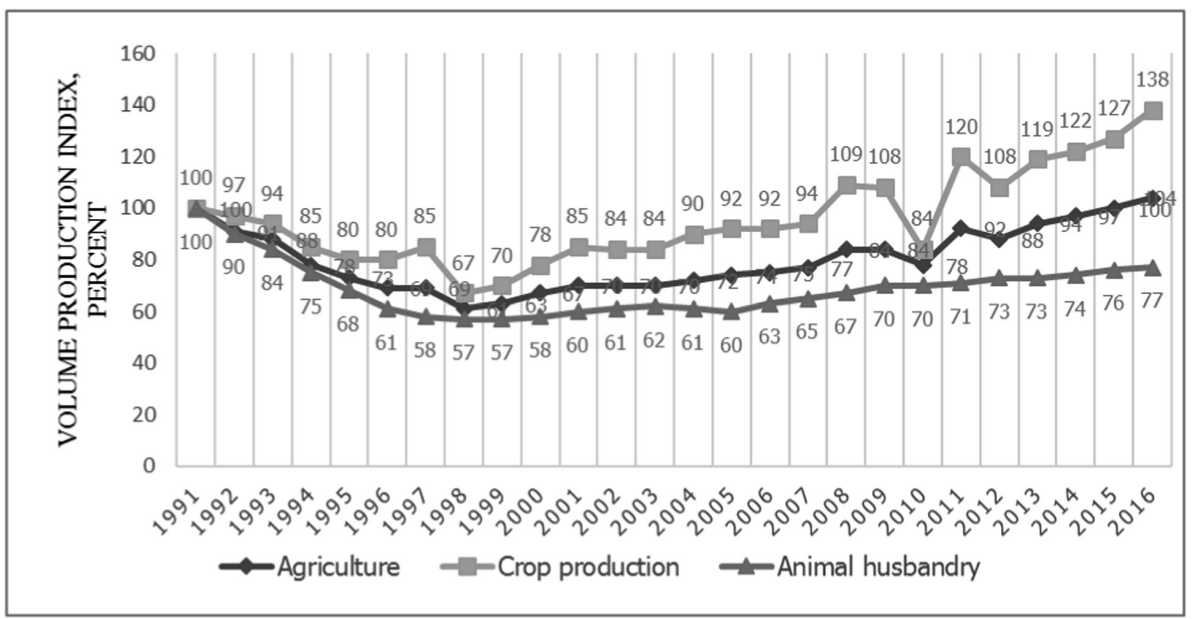

Fig. 1. Volume indexes of agro industrial complex production in percentage terms to the level of 1991. Source: the data of Russia's Federal State Statistics Service, 2017.

The analysis shows that volume indexes of agriculture products are very changeable. They react dynamically to external changes. In 1991 change of Russia's political system led to sharp reduction of production volume in agriculture. Then crisis in 1998 caused the decline of agriculture. Volumes of output were sharply reduced in 2010 and in 2012. Since 2014 stable growth of volume indexes of agriculture production in Russia has been observed.

Let's present some added cost index numbers of Russia's GDP according to following sections of economic activities: agriculture, mining operations and processing manufacture in established prices (Fig. 2).

The analysis shows the increase of gross added cost of Russia's GDP according to all kinds of economic activities. Herewith, growth rate of agriculture is behind of mining operations and processing manufacture growth rate. Really, the gross added cost of agriculture production for 15 years of research has increased from 573,75 billion rbl. in 2002 to 3456,30 billion rbl. in 2016 or 6,02 times as much. Gross added cost of processing manufacture production has increased from 2590,94 billion rbl. in 2002 to 10635,76 billion rbl. in 2016 or 6,46 times as much. Whereupon, gross added cost of mining operations production has increased from 1411,65 billion rbl. in 2002 to 7296,59 billion rbl. in 2016 or 11,43 times as much. It is the evidence of intensification of raw-materials nature of Russian economy. 


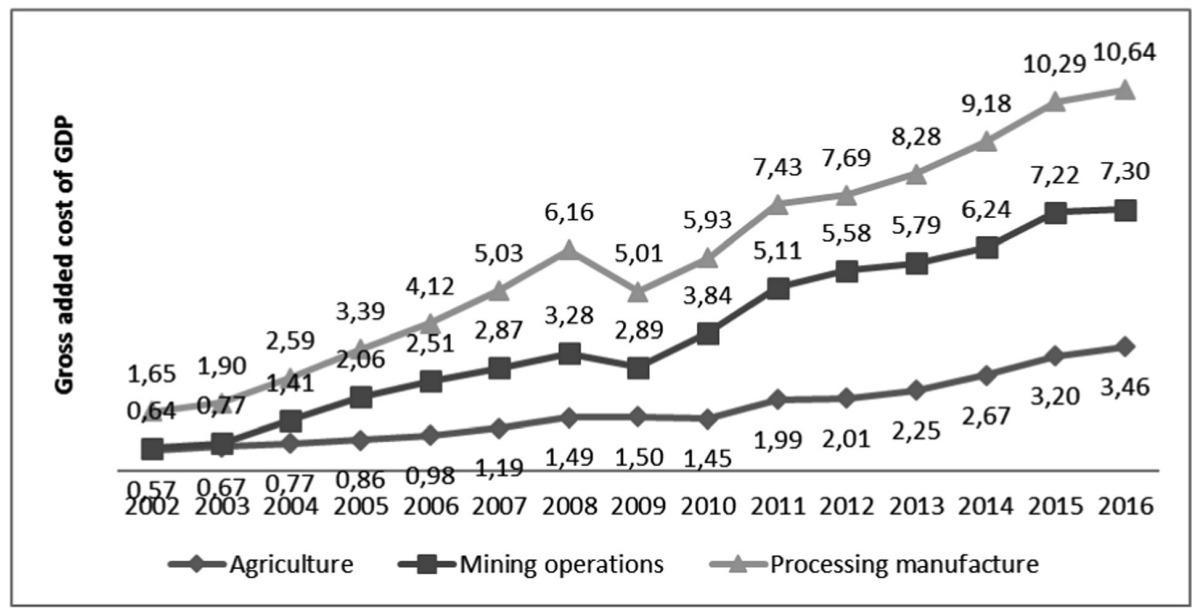

Fig. 2. Gross added cost of Russia's GDP according to some kinds of economic activities in established prices, billion rbl. Source: the data of Russia's Federal State Statistics Service, 2017.

For the better clearness the author has calculated index numbers of GDP volume in market prices and gross added cost according to kinds of economic activities: agriculture (AC), mining operations (MO) and processing manufacture (PM). The results are presented in Table 1.

Table 1. Index numbers of gross added cost volume according to the kinds of economic activities.

\begin{tabular}{l|r|l|l|r|r|r|r|r|r|r|r|r|r|r}
\hline & 2003 & 2004 & 2005 & 2006 & 2007 & 2008 & 2009 & 2010 & 2011 & 2012 & 2013 & 2014 & 2015 & 2016 \\
\hline GDP & 107,3 & 107,2 & 106,4 & 108,2 & 108,5 & 105,2 & 92,2 & 104,5 & 104,3 & 103,5 & 101,3 & 100,7 & 97,2 & 99,8 \\
\hline AC & 98,2 & 101,0 & 100,3 & 102,7 & 101,3 & 106,4 & 101,5 & 87,9 & 114,7 & 98,5 & 104,8 & 102,0 & 103,0 & 103,6 \\
\hline MO & 110,8 & 113,3 & 101,5 & 97,1 & 97,8 & 101,0 & 97,6 & 106,6 & 103,4 & 102,0 & 96,5 & 102,0 & 100,2 & 100,3 \\
\hline PM & 108,8 & 108,1 & 104,4 & 106,6 & 107,5 & 97,9 & 85,4 & 108,6 & 106,3 & 105,4 & 104,4 & 100,8 & 95,4 & 101,1 \\
\hline
\end{tabular}

Source: the data of Russia's Federal State Statistics Service, 2017, authors' calculations

In The analysis shows that tendencies of change of index numbers of the agriculture gross added cost volume do not coincide with change tendencies of other kinds of activity and GDP index numbers in whole. It is possible to single out some distinctive moments. Sharp decrease of gross added cost of processing manufacture and mining operations domestic product took place in 2009. It was the period when world economic crisis manifested itself most strongly. Agriculture indicators in 2009 continued to grow. Manufacture stagnation in agriculture matured in 2010 and in 2012. During this period of time indicators of processing manufacture and mining operations, on the contrary, grew. Therefore, besides influence of internal and external factors some special factors have an influence on agriculture developments. 
Author produce the results of calculations of agriculture, mining operations and processing manufacture shares in Russia's GDP structure (Fig. 3).

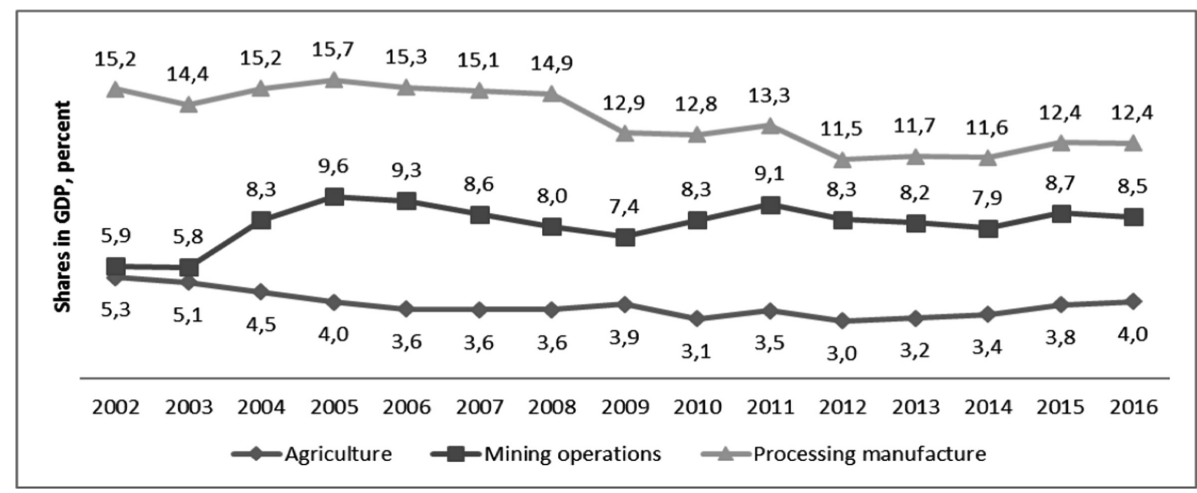

Fig. 3. Agriculture, mining operations and processing manufacture shares in Russia's gross domestic product structure. Source: the data of Russia's Federal State Statistics Service, 2017, authors' calculations.

The analysis shows that agriculture share in GDP structure has decreased since 2002. The first sharp leap downwards was marked in 2010: the indicator was 0,8 points down $(9,33 \%$ down from the previous year value) and reached a 3,1\% - point level in GDP structure. The second sharp leap downwards was marked in 2012: the indicator was 0,5 points down $(5,21 \%$ down from the previous year value) and reached a 3,0\% point level in GDP structure. It was the least value over all research period. Constant and stable growth of agriculture share in Russia's GDP structure has been since 2014. In 2016 the agriculture share took up 4,0\% position in GDP structure.

On the contrary, the mining operations share in Russia's GDP structure has essentially increased since 2002. The growth peak fell on 2003-2005 and 2009-2011. In 2016 mining operations share made up 8,5\% position in GDP structure. It is twice as much as agriculture share.

The processing manufacture share in Russia's GDP structure is the greatest. The indicator value essentially fluctuated over a period of the research. The growth peak fell on 2003-2005 and 2010-2011. In this respect the tendency of the indicator change is similar to laws of change of the indicator of the mining operations share. In 2016 the processing manufacture share made up $12,4 \%$ in GDP structure. It is 3,1 times as much as agriculture share, and 1,5 times as much as mining operations share.

In Table 2 the correlation matrix between indicators of Russia's produced GDP in established prices according to AQEAK sections is presented: agriculture (AC), mining operations (MO) and processing manufacture (PM) and appropriate shares in Russia's GDP structure.

The analysis shows that the agriculture share in GDP structure is directly proportional to the processing manufacture share (correlation coefficient $\mathrm{k}=0,56$ ) and inversely proportional to mining operations share (correlation coefficient $\mathrm{k}=0,64$ ). 
Thus, when mining sectors role of Russia's economy increases, agriculture role reduces. The volume of agriculture production increases and decreases synchronically with processing manufacture production.

High correlation of produced GDP indicators according to AQEAK sections is revealed. Correlation coefficients vary from 0,97 to 0,99 . It can be explained by the fact that the inflation exerts material influence on indicators growth. Price surge caused by the inflation, influences all kinds of production (Fernández 2016; Stigler 1971; Swinnen et al. 2016; Bagwell and Staiger 2006; Skufina et al. 2015). Growth of indicators values of produced GDP is caused, first of all, by the inflation and secondly, by the intensity of production activity.

For elimination of the inflation influence a number of indicators of GDP and its components in comparable prices have been considered. 2011 was assumed as a basis. We will present a number of gross added cost indicators of Russia's GDP according to the following sections of economic activities: agriculture, mining operations and processing manufacture in comparable prices (Fig. 4).

Table 2. Correlation matrix between indicators of Russia's produced gross domestic product according to AQEAK sections and appropriate shares in Russia's gross domestic product structure.

\begin{tabular}{|c|c|c|c|c|c|c|c|c|}
\hline & & \multicolumn{3}{|c|}{$\begin{array}{l}\text { Share in GDP } \\
\text { structure }\end{array}$} & \multicolumn{4}{|c|}{$\begin{array}{l}\text { GDP according to } \\
\text { AQEAK sections }\end{array}$} \\
\hline & & $\mathrm{AC}$ & MO & PM & $\mathrm{AC}$ & MO & PM & GDP \\
\hline \multirow[t]{3}{*}{ Share in GDP structure } & $\mathrm{AC}$ & 1 & & & & & & \\
\hline & MO & $-0,64$ & 1 & & & & & \\
\hline & PM & 0,56 & $-0,03$ & 1 & & & & \\
\hline \multirow[t]{4}{*}{ GDP according to AQEAK sections } & $\mathrm{AC}$ & $-0,48$ & 0,30 & $-0,79$ & 1 & & & \\
\hline & MO & $-0,64$ & 0,42 & $-0,82$ & 0,97 & 1 & & \\
\hline & PM & $-0,64$ & 0,41 & $-0,80$ & 0,98 & 0,99 & 1 & \\
\hline & GDP & $-0,63$ & 0,34 & $-0,86$ & 0,97 & 0,99 & 0,99 & 1 \\
\hline
\end{tabular}

Source: the data of Russia's Federal State Statistics Service, authors' calculations.

The analysis shows that domestic production growth (q.v. Fig. 1), was to a considerable degree caused by increase in prices because of inflation. Transfer of results to the comparable prices gave an opportunity to reveal following tendencies. Actually processing manufactures product slowly grew from 2011 to 2014. Mining operations product practically did not change. The agriculture product was reduced in 2012 and after that started to grow. Growth rate of agriculture have especially increased since 2014.

Correlation matrix between indicators of Russia's produced GDP according to AQEAK sections is presented in Table 3: agriculture (AC), mining operations (MO) and processing manufacture (PM) in established and comparable prices of 2011 . 


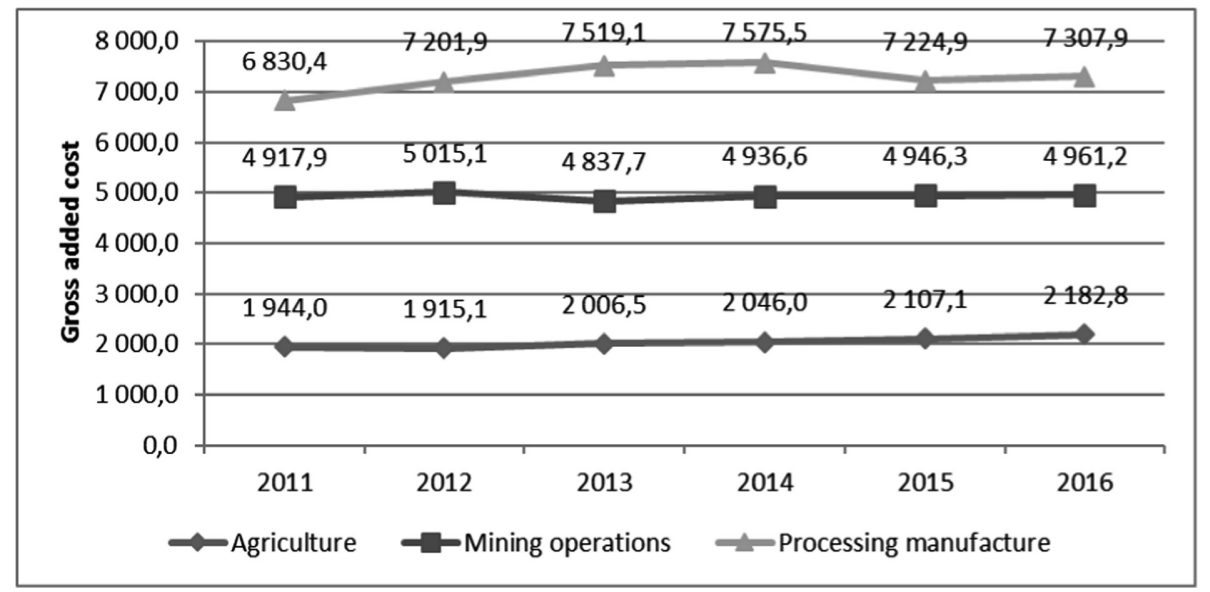

Fig. 4. Gross added cost of Russia's domestic product according to some kinds of economic activities in comparable prices, billion rbl. Source: the data of Russia's Federal State Statistics Service.

Table 3. Correlation matrix between indicators of produced gross domestic product according to AQEAK sections in established and comparable prices of 2011.

\begin{tabular}{|c|c|c|c|c|c|c|c|c|c|}
\hline & & \multicolumn{4}{|c|}{$\begin{array}{l}\text { GDP according to the sections in } \\
\text { prices of } 2011\end{array}$} & \multicolumn{4}{|c|}{$\begin{array}{l}\text { GDP according to the } \\
\text { sections in established prices }\end{array}$} \\
\hline & & $\mathrm{AC}$ & MO & PM & GDP & $\mathrm{AC}$ & MO & PM & GDP \\
\hline \multirow{4}{*}{$\begin{array}{l}\text { GDP according to the } \\
\text { sections in prices of } 2011\end{array}$} & AC & 1 & & & & & & & \\
\hline & MO & $-0,02$ & 1 & & & & & & \\
\hline & PM & 0,35 & $-0,27$ & 1 & & & & & \\
\hline & GDP & 0,07 & $-0,18$ & 0,95 & 1 & & & & \\
\hline \multirow{4}{*}{$\begin{array}{l}\text { GDP according to the } \\
\text { sections in established prices }\end{array}$} & AC & 0,93 & 0,19 & 0,36 & 0,14 & 1 & & & \\
\hline & MO & 0,94 & 0,19 & 0,36 & 0,14 & 0,98 & 1 & & \\
\hline & PM & 0,97 & 0,12 & 0,37 & 0,13 & 0,99 & 0,99 & 1 & \\
\hline & GDP & 0,89 & 0,13 & 0,62 & 0,42 & 0,92 & 0,95 & 0,95 & 1 \\
\hline
\end{tabular}

Source: the data of Russia's Federal State Statistics Service.

AQEAK sections continues to show high indicators correlation. It confirms material influence of inflation on indicators change. The correlation of indicators in the comparable prices, on the contrary, has not been revealed with the exception of high coefficient of correlation between processing manufacture product and GDP $(\mathrm{k}=0,95)$. Among the indicators in established and comparable prices only the correlation in agriculture $(\mathrm{k}=0,93)$ has been revealed. For all other kinds of activity the correlation has not been revealed. 


\subsection{Discussion of Results}

A. The dynamics of agriculture development in Russia's economy.

The fulfilled researches have shown that in whole in the course of 15 years of research the increase in output of agro industrial complex has been low. It is behind of mining operations and processing manufactures indicators. It can be seen in Table 1 and Fig. 2.

The agriculture share in GDP structure is small. From 2002 to 2016 it was 1,2\% down. It can be seen in Fig. 3.

Thus, the hypothesis that agriculture is one of most dynamically developing sectors in Russia's economy has not been confirmed.

B. Reaction of Russia's agro industrial complex to external factors influence.

In 1991 Russia's political system change was followed by rupture of economic and financial ties and stoppage of industrial activity of enterprises. At a later date the situation in Russia's economy became stabilized (Skufina et al. 2015).

Agriculture development in Russia is associated with special problems. First of all, it is a question of objective problems of natural and climatic character (Samarina 2008). The most part of Russia's territory is located beyond the bounds of polar circle. Agricultural activity is complicated with low temperatures, long heating season and sunlight lack. It leads to increase of agricultural production costs and decrease of profitableness of agricultural enterprises activity. The subjective reasons are the following: low level of post-Soviet agriculture technological development, rural population migration, lack of competent management.

It can be seen in Tables 2 and 3 that inflation and other macroeconomic factors have the same influence on all key sectors of Russian economy. Growth of GDP and its components is provided in many ways with increase in prices owing to inflation. Shared problems showed up in full in agriculture.

But the carried out analysis has also shown that tendencies of agriculture development are not always commensurate with tendencies of Russia's economy development in whole. The analysis of Table 3 shows that correlation between indicators of agriculture and other GDP components is absent. Moreover, only agriculture shows correlation between values in established and comparable prices. It makes possible to draw a conclusion that special factors have influence on Russian agro industrial complex development.

Thus, the hypothesis that Russia's agro industrial complex dynamically reacts to external changes has been confirmed.

C. Influence of economic and political factors on agro industrial complex development.

Russia's agro industrial complex is economically ineffective owing to climatic, economic and managerial reasons. It was shown up especially strongly during first ten years of modern Russia development. Focus of agricultural policy on farms development reduced the state support of factory-farm enterprises (Samarina et al. 2016). An efficiency of agriculture was reduced in leaps and bounds. It can be seen in Fig. 1.

The situation in Russia then was typical. State support decrease often and everywhere caused agricultural production crisis. It was noted by many researchers (Baldwin 1985; Olson 1965; Stigler 1971; Anderson 2009). 
In the beginning of $21^{\text {st }}$ century things in agrarian sector were put in order, agricultural loans issues were organized and nowadays agriculture is one of the most fastgrowing sectors of economy. The package of state support measures was approved. In whole taking state support measures and other factors led to agricultural productivity growth in $21^{\text {st }}$ century. Volumes of output in crop production increased especially strongly. It can be seen in Fig. 1. Natural conditions promoted overcoming the crisis as well. In 2008-2009 existing favorable climatic and weather conditions on the greater part of Russia's territory made it possible to get rich harvest of cereal crops and other plant growing products.

It was to be expected that common economic revival in Russia and the state support would bring about the agriculture becomes one of the most fast-growing sectors of economy. But the growth targets can not be called stable and dynamical.

In 2010 sharp decline in output of agriculture products was mentioned. Agriculture share in GDP structure was reduced as well. At the same time total economic expansion growth took place. The crisis was caused by the drought and as consequence poor harvest of cereal crops, vegetables and fruit. Sharp setback in crop sector production can be seen in Fig. 1. The latest period of time was not the most successful for Russian agro industrial complex.

The next crisis fell on 2012. This year climatic and weather conditions were favorable enough. The crisis was to a considerable degree caused by some economic and political reasons and weakening of state support of agro industrial complex. It was the consequence of Russia's joining the World Trade Organization.

Joining the World Trade Organization (WTO) in August, 2012 limited state possibilities of domestic producers support. Russia's food safety turned out under the threat.

And against this background a new factor suddenly appeared: the USA, countries of the European Union, Canada, Australia and Norway's sanctions limiting Russia's foreign trade activities.

It is necessary to note that foreign sanctions influence on Russian agriculture is insignificant, at least at present. First of all, sanctions infringe on financial, energy and defense-industrial branches, and also infringe on some officials, businessmen and companies' interests that are not related to agrarian and industrial complex. On the contrary, Russian retaliatory countersanctions directly related to agriculture and food industry. Veto on foodstuff import became a primary cause of sharp reduction in imports in 2014. Further countersanctions were prolonged for 2015, 2016 and 2017. To all appearance, food embargo will be prolonged at least till the end of 2018.

Realization of state protectionism policy led to agricultural production growth. This growth began in 2014 and has been in progress up to date. It can be seen in Figs. 1 and 2.

The gross added cost of Russia's agricultural products started to grow. Thus, volume indexes of gross added cost of processing manufacture and mining operations were behind of agriculture indicators. It can be seen in Table 1.

Thus, the hypothesis that economic and political factors besides natural and climatic ones exert a substantial influence on agriculture development has been confirmed. 
D. Problems of agricultural manufacturers development in the conditions of countersanctions actions.

At the same time it is possible to note a number of substantive problems of agricultural manufacturers development in the conditions of sanctions and countersanctions actions.

Firstly, sanctions in financial field can complicate Russian enterprises (including agricultural) access to foreign investments and credits.

Secondly, import substitution is not quantitative but rather qualitative growth of manufacture. And it is not one day business. At the same time a ban on food import, including agricultural products, has been already put. In this situation the problem of price surge restraint for Russia's population and especially Russia's northern regions is the major.

Thirdly, despite the essential state support the question of Russian agriculture possibilities promptly compensate forbidden import agricultural production, raw materials and foodstuffs: meat products, vegetables, fruit, etc. remains open.

Fourthly, there might be such circumstances that niches appeared in the market of agricultural products will be filled up not with domestic production, but with import from those countries which did not attach punitive anti-Russian sanctions.

Finally, both western sanctions, and Russian countersanctions have political genesis. This implies that in case of a political situation change they can be instantly suspended or completely cancelled, or on the contrary intensified. Owing to unsolved Ukrainian crisis it is difficult enough to predict further development of relations between Russia and the West for any long period. It is not clear what sanctions will be adopted by the West in case of intensifying of confrontation: such ones which will damage Russian agro industrial complex directly can be among them. Therefore, along with chance of sustainable development with powerful state support which Russia's agriculture and its separate regions gained, some additional risks appeared and uncertainty increased.

The influence of problems on steady growth of agricultural production in the conditions of the state protectionism can be seen in Figs. 1 and 2. The domestic added cost of Russia's agricultural products in 2014 began to grow. But indicators research in comparable prices in Fig. 4 shows that growth rates were insignificant.

Thus, the hypothesis that countersanctions undoubtedly have positive influence on agricultural production development in Russia has not been confirmed.

The analysis has shown essential dependence of development of Russia's agriculture on some external conditions, including economic and political factors. In turn agrarian policy has no any essential influence upon policy. Therefore, it is necessary to strengthen agro industrial complex from within in order to increase external economic and political factors resistance.

It is a question of Russia's agriculture domestic support i.e. part of national agriculture state support, carried out in the area of domestic agrarian policy.

In conditions of economy globalization and according to WTO rules state support of the country should be carried out on the basis of certain mechanisms of rendering assistance to agriculture (Josling 2000; Alston and Pardey 2014). "Green box" provides measures of support which do not have perverse influence on international trade and can be used without any restrictions such as support to meet the institutional 
development of agriculture. In our opinion, such measures as development of rural infrastructure, carrying out of agro industrial scientific research, working out of new kinds in plant growing and new breeds in animal industries, targeted payments to farmers in case of their wasteful production etc. will become effective. It should be noted that Russian Government has not enough promoted in the line of state support in the network of "Green box".

"Blue box" measures meet the restriction of certain agricultural products manufacture. In Russian agrarian policy these measures practically are not used. Considered analysis, loss estimate and prospects of conversion to a new kind of activity for agriculture enterprises should precede these measures use. The government should develop comprehensive support measures for these agricultural manufacturers. WTO rules do not restrict appropriated means for realization of "Blue box" measures.

At present the majority of state support measures apply to so called "Amber box". These direct and indirect measures of agro industrial complex support directly influence volumes and cost price of domestic manufacture products. The use of countersanctions and state protectionism applies to "Amber box" measures. At present these measures are effective. They give essential support to Russia's agriculture. But according to WTO rules, "Amber box" volume is subject to obligatory reduction.

At the present time conversion to rendering assistance of the state help to Russian agriculture by way of "Blue box" and "Green box" measures will have a negative effect. However, Russia's activity as a part of WTO compels Russia to give up "Amber box" protectionist measures.

\section{Conclusion}

1. Over a period of time from 2002 for 2016 the increment of agro industrial complex output was reduced. The agriculture share in GDP structure was reduced as well. The hypothesis that agriculture is one of most dynamically developing sectors in Russia's economy has not been confirmed.

2. Inflation and other macroeconomic factors have identical influence on all leading sectors of Russian economy. At the same time Russia's agriculture development is associated with a whole number of special problems. The hypothesis that Russia's agro industrial complex dynamically reacts to external changes has been confirmed.

3. In 2012 the crisis was revealed in agro industrial complex activity. That year climatic and weather conditions were favorable enough. The crisis was substantially caused by some economic and political reasons and weakening of agro industrial complex state support. On the contrary, the realization of state protectionism policy in 2014 led to agricultural production growth. Thus, the hypothesis that besides natural and climatic factors some special economic and political ones have material influence on agriculture development has been confirmed.

4. There is a number of problems of agricultural manufacturers development in the conditions of sanctions and countersanctions actions: complexity in drawing up and getting foreign investment of capital for agriculture enterprises; industrial and technological possibilities of import substitution; long term of import substitution process in agriculture; possibility of arrival of foreign suppliers with cheaper 
agricultural production at the Russian market; uncertainty in countersanctions preservation and protectionism conditions. Thus, the hypothesis that countersanctions undoubtedly exert positive influence upon Russia's agricultural production development has not been confirmed.

5. At present the majority of state support measures apply to so called "Amber box". However Russia's activity as a part of WTO compels it to give up "Amber box" protectionist measures in favour of "Blue box" and "Green box" measures. In our opinion, such measures as development of rural infrastructure, carrying out of agroindustrial scientific research, working out of new kinds in plant growing and new breeds in animal industries, targeted payments for farmers in case of their wasteful production etc. It is necessary to lay special stress on working out measures of all-round help within WTO rules framework for agro industrial complex enterprises changing their line of business because of restriction of certain agricultural products manufacture.

Acknowledgement. The article is performed with the support of the grant of Russian Foundation for Basic Research (RFBR), no. 17-12-31003.

\section{References}

All-Russian qualifier of economic activities kinds (2017)

Alston, J.M., Pardey, P.G.: Agriculture in the global economy. J. Econ. Perspect. 28(1), 121-146 (2014)

Anderson, K.: Distorted agricultural incentives and economic development: Asia's experience. World Econ. 32(3), 351-384 (2009)

Bagwell, K., Staiger, R.W.: Will international rules on subsidies disrupt the World trading system? Am. Econ. Rev. 96(3), 877-895 (2006)

Baldwin, R.E.: The Political Economy of Us Import Policy. MIT Press, Cambridge (1985)

Barberis, N.C.: Thirty years of prospect theory in economics: a review and assessment. J. Econ. Perspect. 27(1), 173-196 (2013)

Fernández, E.: Politics, coalitions, and support of farmers, 1920-1975. Eur. Rev. Econ. Hist. 20 (1), 102 (2016)

de Gorter, H., Swinnen J.F.M.: Political economy of agricultural policy. In: Gardner, B., Rausser, G. (eds.) Handbook of Agricultural Economics, vol. 2B, pp. 1893-1943 (2002)

Gross Domestic Product: Russia's federal state statistics service data (2017). http://www.gks.ru/ wps/wcm/connect/rosstat_main/rosstat/ru/statistics/accounts/\#. Accessed 16 Nov 2017

Guariso, A., Squicciarini, M.P., Swinnen, J.: Food price shocks and the political economy of global agricultural and development policy. Appl. Econ. Perspect. Policy 36(3), 387-415 (2014)

Josling, T.: New farm program in North America and their treatment in the WTO: discussion. Am. J. Agric. Econ. 82(3), 775-777 (2000)

Olson, M.: The Logic of Collective Action. Harvard University Press, Cambridge (1965)

Samarina, V.P.: Effect of engineering-industrial activities in the region of the Kursk magnetic anomaly on the ecological state of the river waters. Geochem. Int. 46(9), 928-934 (2008) 
Samarina, V.P., Skufina, T.P., Samarin, A.V., Baranov, S.V.: Some problems of antirecessionary public management in Russia at present. Management of Systems of Socio-economic and Legal Relations in Modern Conditions of Development of Education and Society 6(6), 38-44 (2016). http://econjournals.com/index.php/irmm/article/view/2917. Accessed 22 July 2017

Skufina, T., Baranov, S., Samarina, V., Shatalova, T.: Production functions in identifying the specifics of producing gross regional product of Russian Federation. Mediterr. J. Soc. Sci. 6(5, Suppl. 3), 265-270 (2015). https://doi.org/10.5901/mjss.2015.v6n5s3p265

Stigler, G.J.: The theory of economic regulation. Bell J. Econ. Manag. Sci. 2(1), 3-21 (1971)

Swinnen, J., Olper, A., Vandemoortele, T.: The political economy of policy instrument choice: theory and evidence from agricultural and food policies. Theor. Econ. Lett. 6(1), 97-105 (2016)

Swinnen, J.F.M.: The growth of agricultural protection in Europe in the 19th and 20th centuries. World Econ. 32(11), 1499-1537 (2009) 